\title{
Kapasitas dan Kinerja Pengelolaan Usaha Akuakultur Anggota Kelompok Pembudidaya Ikan di Kabupaten Tasikmalaya
}

\author{
[Capacity and Performance of Fish Farmer Group Members \\ in Aquaculture Business Management in Tasikmalaya District]
}

\author{
Aan Hermawan ${ }^{\square}$ \\ Sekolah Tinggi Perikanan, Jurusan Penyuluhan Perikanan \\ Jalan Cikaret Nomor 2, Bogor 16132, Jawa Barat \\ Diterima: 20 Oktober 2017; Disetujui: 30 November 2017
}

\begin{abstract}
Abstrak
Penelitian ini menganalisis kapasitas dan kinerja pengelolaan usaha akuakultur anggota kelompok pembudidaya ikan, dan menganalisis faktor-faktor dominan yang memengaruhinya. Penelitian survey dilaksanakan di Kabupaten Tasikmalaya, pada bulan Januari sampai Februari 2016, dengan responden penelitian sejumlah 105 orang anggota kelompok pembudidaya ikan yang dipilih secara acak kelompok. Hasil penelitian menunjukkan kapasitas anggota kelompok pembudidaya, yang mencakup kemampuannya mengakses input produksi, mengelola proses produksi (on farm), dan memasarkan hasil produksi tergolong pada kategori sedang sampai tinggi. Kinerja usaha menguntungkan dan layak dari variabel pendapatan, namun keberadaan kelompok bagi anggota belum mampu meningkatkan produktivitas usaha budidaya ikan. Hasil analisis SEM menunjukkan karakteristik pembudidaya ikan, dukungan kondisi kelompok, dukungan layanan penyuluhan, dan keterlibatan pembudidaya dalam kelompok, positif signifikan memengaruhi kapasitas pembudidaya ikan dalam pengelolaan usaha. Hanya variabel dukungan kelompok yang berpengaruh negatif signifikan terhadap tingkat produktivitas usaha dan berpengaruh positif signifikan terhadap tingkat pendapatan pembudidaya ikan, yang mengindikasikan perlu adanya perbaikan manajemen kelompok pembudidaya ikan.
\end{abstract}

Kata kunci: akuakultur, kapasitas, kelompok, kinerja, pembudidaya ikan.

\begin{abstract}
This research was aimed to analyze capacity and performance of fish farmer group members in aquaculture business management, and to analyze dominant variables that influence it. The research was conducted in Tasikmalaya District, from January to February 2016 with the number of the respondents was 105 fish farmers selected using cluster random sampling. The results showed the capacity of fish farmers, including the ability to access production inputs, to production manage (on farm), and production marketing in the medium to high category. Aquaculture is profitable and feasible on income variables, but the group existence hasn't increased the productivity of aquaculture business. The results of SEM analysis indicated fish farmers' characteristics, group supporting factor, support of extension services, and farmers' participation in the group positively significant affecting the fish farmers' capacity in business aquaculture management. Only group supporting variable is negatively significant affecting to aquaculture productivity level and has positive significant affecting to fish farmers' income, which indicated there should be an improvement in the fish farmers' group management.
\end{abstract}

Keywords: aquaculture, capacity, fish farmers, group, performance.

\footnotetext{
$\triangle$ Penulis Korespondensi :

Aanhermawan84@gmail.com
} 


\section{PENDAHULUAN}

Perikanan budidaya (akuakultur) sangat potensial dalam meningkatkan pendapatan dan kesejahteraan rakyat, mampu menghasilkan pertumbuhan ekonomi tinggi (di atas $7 \%$ per tahun), inklusif (banyak menyerap tenaga kerja), dan berkelanjutan (Dahuri 2016). Pada skala tradisional, akuakultur memberikan kontribusi besar bagi pasokan pangan rumah tangga, gizi dan kesehatan, penyedia lapangan pekerjaan dan pendapatan di pedesaan. Akuakultur bahkan berkontribusi mengurangi kemiskinan di beberapa wilayah dunia, antara lain di China, Indonesia dan Vietnam (Edwards 2000).

Pembudidaya ikan di negaranegara berkembang terutama pembudidaya berskala kecil (small scale fisheries) selalu menghadapi tantangan dalam menjalankan usahanya. Adanya ASEAN Economic Community pada tahun 2015 dan perdagangan bebas antar negara menuntut para pelaku pasar untuk meningkatkan daya saing produknya. Pasar komoditas perdagangan dan jasa akan bersaing ketat sehingga produk akuakultur harus berkualitas unggul dengan biaya produksi yang lebih efisien. Pembudidaya juga dituntut menerapkan Good Aquaculture Practice melalui CBIB (Cara Budidaya Ikan yang Baik) dan CPIB (Cara Pembenihan Ikan yang Baik) untuk peningkatan kualitas dan jaminan keamanan produk budidaya.

Menghadapi tantangan tersebut, pembudidaya ikan harus lebih adaptif menghadapi perubahan dan mampu mengembangkan usaha perikanannya berorientasi bisnis. Faktanya, pembudidaya masih terbatas kemampuannya dalam menghasilkan ikan yang sesuai dengan permintaan pasar dari segi kualitas dan kuantitas (FAO 2008). Skala usaha perikanan yang kecil menghambat pembudidaya ikan meningkatkan pendapatannya. Pembudidaya sulit meningkatkan produktivitasnya karena aksesibilitas rendah terhadap modal, teknologi, informasi dan pasar, serta rendahnya kapasitas (Edward 2000). Proses produksi akuakultur di pedesaan (rural aquaculture) juga mengindikasikan produksi berbiaya rendah dengan teknologi ekstensif dan semi intensif sesuai dengan keterbatasan sumberdaya yang dimiliki oleh pembudidaya skala kecil (Edwards 2000; Demaine 2009).

Penelitian Fatchiya (2010) menunjukkan pembudidaya ikan memiliki kapasitas yang rendah dalam 
pengelolaan usahanya, baik dalam menjalankan fungsi-fungsi usaha, memecahkan masalah, perencanaan evaluasi, dan kemampuan adaptasinya terhadap perubahan. Faktor utama penyebab rendahnya kapasitas ini adalah kurangnya frekuensi kegiatan penyuluhan yang diikuti oleh pembudidaya, rendahnya dukungan lembaga penyedia input produksi, tingkat pendidikan formal pembudidaya yang rendah, dan lemahnya kinerja penyuluh perikanan dalam memberikan proses pembelajaran kepada pembudidaya. Lemahnya kapasitas pembudidaya ini berakibat pada usahanya menjadi kurang berkembang.

Mekanisme efektif untuk membantu para pembudidaya ikan skala kecil dalam menghadapi tantangan tersebut adalah dengan aksi bersama dalam kelompok. Penelitian FAO (2011) di India dan Thailand menunjukkan bahwa keterlibatan bersama dalam pembentukan dan pelaksanaan manajemen kelompok menjadi alat yang efektif untuk meningkatkan tata kelola sektor perikanan budidaya berskala kecil. Manajemen kelompok memungkinkan pembudidaya untuk bekerja sama, meningkatkan produksi, mengembangkan skala ekonomi yang cukup, terlibat dalam rantai pasar modern, dan meningkatkan kehandalannya dalam produksi dan mengurangi resiko. Shresta et al. (2012) menyatakan pula bahwa pembudidaya ikan sedapat mungkin membentuk kluster (kelompok). Kelompok ini membantu membangun hubungan dengan kantorkantor pemerintah dan memberi kekuatan untuk menuntut layanan/dukungan usaha.

Pertanyaan dalam penelitian ini adalah; (1) Bagaimana kondisi kemampuan pembudidaya ikan yang tergabung dalam kelompok, dalam mengelola usahanya sehingga berdampak pada produktivitas dan pendapatannya?; (2) Faktor-faktor apa yang memengaruhi kapasitas dan kinerja pembudidaya ikan dalam mengelola usahanya? Pengaruh faktor-faktor ini didentifikasi dari karakteristik sosial ekonomi pembudidaya ikan, eksistensi kelompok, tingkat dukungan layanan penyuluhan, dan tingkat keterlibatan pembudidaya ikan dalam kegiatan kelompok. Dengan demikian penelitian ini bertujuan untuk; (1) Menganalisis kapasitas dan kinerja pengelolaan usaha anggota kelompok pembudidaya ikan; dan Menganalisis faktor-faktor dominan yang memengaruhi kapasitas pengelola- 
an usaha dan kinerja usaha anggota kelompok pembudidaya ikan.

Penelitian dilakukan di Kabupaten Tasikmalaya, sebagai salah satu sentra budidaya ikan air tawar dan representasi rural aquaculture di Provinsi Jawa Barat. Usaha akuakultur sebagian besar di kolam air tenang pada skala kecil maupun secara terintegrasi di lahan sawah (mina padi), dimana keberadaan kelompok memiliki peran penting dalam kegiatan usaha pembudidaya ikan.

\section{METODE PENELITIAN}

Penelitian ini menggunakan rancangan penelitian survei yang bersifat penjelasan (explanatory research) dengan pendekatan kuantitatif sebagai dasar analisis. Lokasi penelitian di 8 kecamatan dari 39 kecamatan di Kabupaten Tasikmalaya, yaitu Kecamatan Padakembang, Sukarame, Sukaratu, Singaparna, Sariwangi, Sukaraja, Manonjaya, dan Gunung Tanjung. Pengambilan data dilakukan pada bulan Januari sampai Februari 2016.

Populasi penelitian adalah 351 orang pembudidaya ikan pada 31 kelompok yang masih aktif dan dibina oleh penyuluh perikanan dari 185 kelompok pembudidaya ikan di
Kabupaten Tasikmalaya. Dengan teknik cluster random sampling, ditetapkan 105 orang pembudidaya ikan dari 10 kelompok sebagai responden penelitian atau $30 \%$ dari populasi.

Varibel utama yang dikaji sebagai data penelitian adalah variabel endogen kapasitas pembudidaya ikan dalam pengelolaan usaha (Y1), meliputi kapasitas dalam mengelola input produksi, pelaksanaan proses produksi, dan pemasaran hasil perikanan; dan variabel kinerja usaha akuakultur pembudidaya ikan (Y2), meliputi tingkat produktivitas dan pendapatan usaha. Variabel ini dipengaruhi oleh variabel eksogen; (a) karakteristik pembudidaya ikan (XI), meliputi umur, tingkat pendidikan formal, tingkat pendidikan non formal, motivasi berkelompok, pengalaman usaha, skala usaha, tingkat kekosmopolitan, dan lama keanggotaan; (b) dukungan kondisi kelompok (X2), meliputi tujuan kelompok, fungsi kelompok, manfaat kelompok bagi anggota, kepemimpinan ketua kelompok, sarana yang dimiliki kelompok, dan kekompakan kelompok; (c) tingkat dukungan layanan penyuluhan (X3), meliputi intensitas dan peran penyuluh perikanan; dan (d) partisipasi/keterlibatan pembudidaya ikan dalam ke- 
lompok (X4), meliputi frekuensi dan derajat keterlibatan.

Analisis statistika yang digunakan adalah analisis statistika deskriptif dan analisis statistika inferensial berupa analisis Structural Equation Model (SEM) untuk menganalisis pengaruh secara struktural antar variabel baik secara langsung maupun tidak langsung dan menguji model hubungan antar variabel laten (variabel eksogen dan variabel endogen). Hipotesis uji dalam penelitian ini; (1) Kapasitas pembudidaya ikan dalam mengelola usaha dipengaruhi oleh karakteristik individu, faktor dukungan kelompok, tingkat dukungan layanan penyuluhan, dan keterlibatan pembudidaya dalam kelompok; (2) Kinerja usaha budidaya ikan (usaha akuakultur) pembudidaya dipengaruhi oleh kapasitas pengelolaan usaha, keterlibatan pembudidaya dalam kelompok, karakteristik individu, faktor dukungan kelompok, dan tingkat dukungan layanan penyuluhan. 
Kapasitas dan Kinerja Pengelolaan Usaha Akuakultur

Anggota Kelompok Pembudidaya Ikan di Tasikmalaya

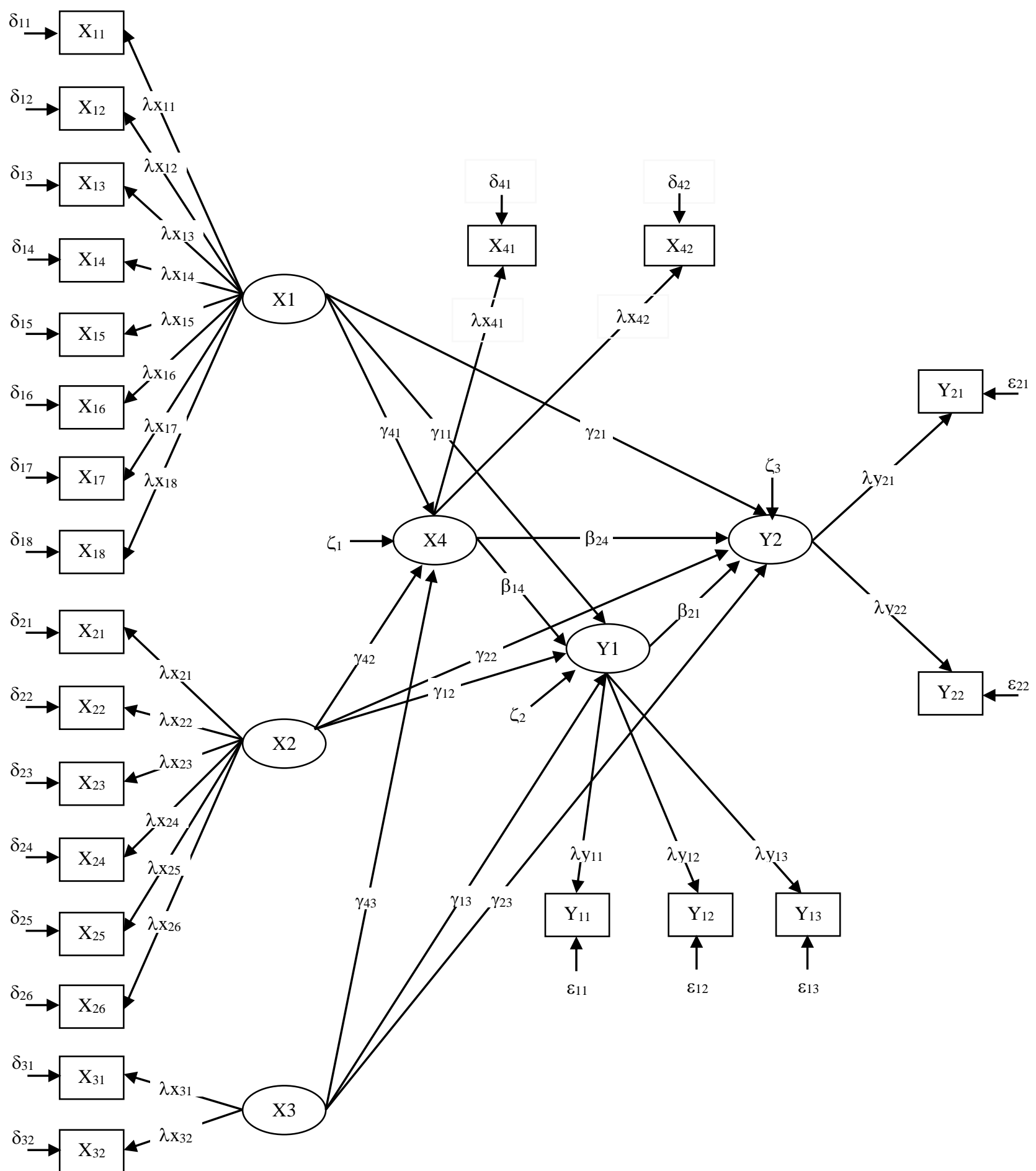

Gambar 1. yang memengaruhi kapasitas pengelolaan usaha dan kinerja usaha anggota kelompok pembudidaya ikan

$\mathrm{X}=$ Variabel manifes untuk variabel laten eksogen

$\mathrm{Y}=$ Variabel manifes untuk variabel laten endogen.

$\lambda \mathrm{x}=$ Lambda-x, koefisien bobot faktor variabel manifes eksogen.

$\delta=$ Theta-delta, kekeliruan pengukuran variabel manifes eksogen $\mathrm{X}$.

$\lambda y=$ Lambda-y, koefisien bobot faktor variabel manifes endogen

$\gamma=$ Gamma, suatu matriks koefisien yang menggambarkan pengaruh dari variabel eksogen (variabel laten $\mathrm{X}$ ).

$\varepsilon=$ Theta-epsilon, kekeliruan pengukuran variabel manifes endogen Y.

$\beta=$ Beta, suatu matriks koefisien yang menggambarkan pengaruh dari variabel endogen terhadap variabel endogen lainnya. 
persamaan struktural untuk memudahkan analisis dan pengolahan data disajikan pada Gambar 1.

\section{HASIL DAN PEMBAHSAN \\ Profil Perikanan Budidaya (Akuakultur) Kabupaten Tasikmalaya}

Kabupaten Tasikmalaya Provinsi Jawa Barat memiliki luas wilayah $2.712,49 \mathrm{~km}^{2}$, secara administrasi terbagi menjadi 39 kecamatan 351 desa. Kabupaten ini memiliki lima aliran sungai besar sebagai sumber air utama yaitu Sub DAS Citanduy Hulu (742,52 Ha), Sub DAS Ciwulan Hulu (16.172,38 Ha), Sub DAS Ciwulan Hilir 2.005 (Ha), Sub DAS Cilangla (181,01 $\mathrm{Ha})$, Sub DAS Cimedang $(2.667,78$ Ha), dan Sub DAS Ciseel (7.258 Ha). Distribusi air ke areal lahan perkolaman dan pesawahan melalui beberapa irigasi, antara lain Irigasi Cikunten I, Cikunten II, Ciramajaya, Cilongan, Bongas, Cimuli, Cikalang, Cikulur, Cipatujah, dan Irigasi Padawaras. Persediaan air untuk perikanan relatif merata sepan-jang tahun dan secara kuantitas relatif dapat mencukupi jumlah kebutuhan. Kondisi potensi dan pemanfaatan lahan perikanan di Kabupaten Tasikmalaya ditunjukkan pada Tabel 1.

Jenis ikan air tawar yang diusahakan oleh pembudidaya ikan beragam terdiri dari Ikan Mas, Nila, Nilem,
Tawes, Gurame, Lele, Tambakan, Udang Galah, Bawal Air Tawar, Mujair, dan Sepat Siam. Lima komoditas utama yang sebagian besar dibudidayakan secara komersial adalah Ikan Mas, Nila, Nilem, Gurame dan Lele. Total dan nilai produksi ikan air tawar selama empat tahun terakhir (tahun 2011-2014) relatif mengalami kenaikan, sedangkan pada Tahun 2015 terjadi penurunan produksi sebesar 9,1\%. Adapun total dan nilai produksi budidaya ikan air tawar di Kabupaten Tasikmalaya selama lima tahun terakhir dapat dilihat pada Gambar 2.

Data laporan tahunan penyuluh perikanan tahun 2014 menunjukkan nilai rerata produktivitas pembenihan ikan air tawar pada kolam tanah adalah sebesar 6.332.904,85 ekor/ha/tahun, sedangkan rerata produktivitas pembesaran ikan air tawar pada kolam tanah sebesar 80,81 kwintal/ha/tahun. Nilai produktivitas ikan air tawar pada lahan budidaya lainnya menunjukan nilai yang berbeda yaitu kolam air deras 42,70 kwintal/unit/tahun, lahan sawah 10,17 kwintal/ha/tahun, dan keramba 28,50 kwintal/unit/tahun. Data luas tanam, produksi, dan produktivitas budidaya ikan air tawar berdasarkan jenis ikan dan wadah budidaya ditunjukkan pada Tabel 2.

Tabel 1 Potensi dan pemanfaatan lahan perikanan di Kabupaten Tasikmalaya

\begin{tabular}{|c|c|c|c|}
\hline No & Jenis Usaha Budidaya Ikan & Potensi & Pemanfaatan \\
\hline \multirow[t]{3}{*}{1.} & Kolam air tenang (ha) & $4.114,27$ & $3.595,06$ \\
\hline & a. Pembenihan (ha) & 366,59 & 299,86 \\
\hline & b. Pembesaran (ha) & $3.747,68$ & $3.295,20$ \\
\hline 2. & Kolam air deras (unit) & 84 & 32 \\
\hline 3. & Lahan sawah (minapadi) (ha) & $6.961,77$ & 5.500 \\
\hline 4. & Keramba jaring apumg (unit) & 150 & 30 \\
\hline 5. & Keramba (unit) & 100 & 74 \\
\hline \multirow[t]{3}{*}{6.} & Perairan umum & & \\
\hline & a. Situ dan rawa (ha) & 172,50 & 122,50 \\
\hline & b. Sungai (km) & 510,50 & \\
\hline 7. & Tambalk air payau (ha) & 200 & 12 \\
\hline
\end{tabular}


Tipe akuakultur di Kabupaten Tasikmalaya secara umum digolongkan pada tipe artisanal aquaculture yaitu produksi dengan skala kecil yang bertujuan untuk dipasarkan. Sistem budidaya yang diterapkan adalah sistem semi intensif, pembudidaya ikan sudah melakukan persiapan wadah budidaya, pemupukan dan pemberian pakan tambahan untuk meningkatkan produksinya. Sebagian besar pembudidaya ikan khususnya pada usaha pembenihan
Kabupaten yang berlokasi di Rancapaku, Cibeuti, Cogreg, dan Pada kembang, dan 3 sub unit Balai Pengembangan Budidaya Ikan Gurame dan Nilem Tingkat Provinsi Jawa Barat yang berlokasi di Leuwisari, Singaparna, dan Mangunreja; (2) Lembaga pembiayaan usaha, antara lain perbankan (BRI) yang menyediakan fasilitas pinjaman/kredit sejumlah 2 unit kantor cabang dan 46 kantor unit di kecamatan; (3) Lembaga pemasaran, meliputi 3 unit pasar ikan yang berlokasi di

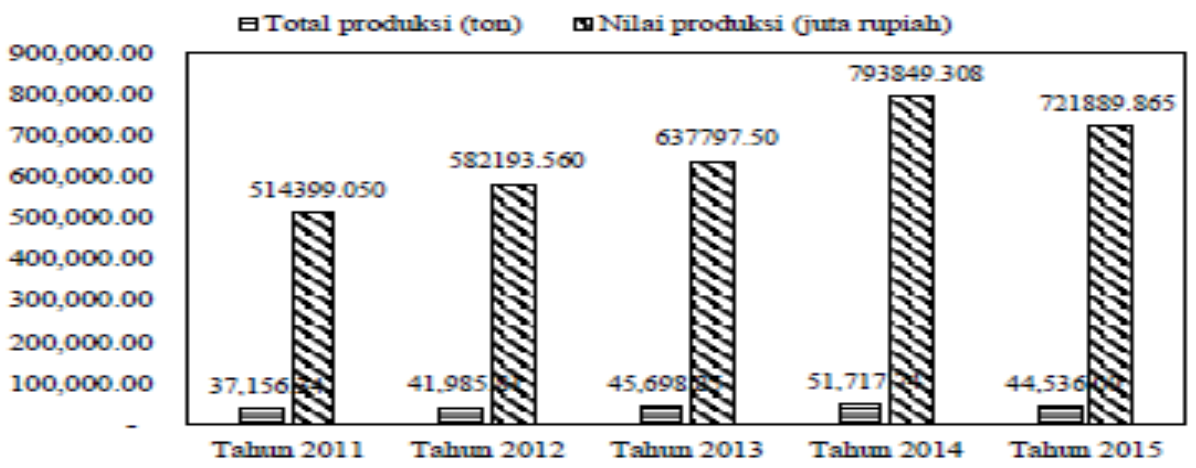

Gambar 2 Total dan nilai produksi budidaya ikan air tawar Kabupaten Tasikmalaya, tahun $2011-2015$

ikan mengusahakan satu jenis ikan sehingga dengan sendirinya pembudidaya ikan terspesialisasi pada komoditas tertentu dan setiap tahapan produksi budidaya dilakukan oleh pembudidaya yang berbeda. Berbeda pada usaha pembesaran ikan, umumnya pembudidaya memelihara beberapa jenis ikan baik secara monokultur maupun polikultur. Keterbatasan lahan usaha, kebiasaan dan penguasaan teknologi, serta permintaan pasar sesuai lokasi menjadi alasan pilihan jenis ikan yang diusahakan pembudidaya.

Kabupaten Tasikmalaya memiliki beberapa lembaga pendukung sebagai penyedia layanan usaha. Lembagalembaga pemerintah yang mendukung pengembangan dan keberlanjutan usaha budidaya ikan; (1) Lembaga penyedia induk dan benih ikan unggul, meliputi 4 Unit Pelaksana Teknis Dinas (UPTD) Pengembangan Benih Ikan Tingkat
Pada kembang, Singaparna, dan Jatihurip; (4) Lembaga penyuluhan khusus perikanan berupa Pos Penyuluhan Perikanan di Padakembang; dan (5) kios-kios penyedia sarana produksi perikanan yang tersebar di desa-desa dan kecamatan.

\section{Kapasitas Pengelolaan Usaha Akuakultur Anggota Kelompok Pembudidaya Ikan}

Kapasitas anggota kelompok pembudidaya ikan dalam mengelola usaha dinilai dari kemampuannya dalam memperoleh input produksi, mengelola proses produksi (on farm), dan memasarkan hasil produksi. Tabel 3 menunjukkan distribusi kapasitas pengelolaan usaha anggota kelompok pembudidaya ikan di Kabupaten Tasikmalaya. 
Tabel 3. Luas tanam, produksi dan produktivitas budidaya ikan air tawar di Kabupaten Tasikmalaya

\begin{tabular}{|c|c|c|c|c|}
\hline No & $\begin{array}{c}\text { Jenis Ikan dan Usaha } \\
\text { Budidaya }\end{array}$ & Luas Tanam & Produksi & Produktivitas \\
\hline \multirow[t]{18}{*}{1.} & Kolam tanah & & & \\
\hline & a. Pembenihan & ha & ekor & ehor/ha/tahun \\
\hline & - Ikan Mas & 89.95 & 664644698 & 7389046.11 \\
\hline & - Ikan Nila & 74.96 & 569965454 & 7599992.72 \\
\hline & - Ikan Nilem & 45.00 & 284847727 & 6329949.49 \\
\hline & - Ikan Tawes & 35.70 & 189898484 & 5319285.27 \\
\hline & - Ikan Gurame & 18.18 & 76771873 & 4222875.28 \\
\hline & - Iran Lele & 17.26 & 75959395 & 4400891.95 \\
\hline & - Ikan lainnya & 18.81 & 37167217 & 1975928.60 \\
\hline & b. Pembesaran & ha & ton & kwintal/ha/tahum \\
\hline & - Ikan Mas & 988.56 & 8002.20 & 80.95 \\
\hline & - Ikan Nila & 823.80 & 7882.25 & 95.68 \\
\hline & - Ikan Nilem & 622.35 & 5552.24 & 83.83 \\
\hline & - Ikan Tawes & 395.42 & 3024.45 & 76.49 \\
\hline & - Ikan Gurame & 105.25 & 510.25 & 48.48 \\
\hline & - Iran Lele & 86.86 & 676.53 & 77.89 \\
\hline & - Ikan lainnya & 232.96 & 979.07 & 42.03 \\
\hline & & unit, ha & ton & kwintal/ha, unit/tahun \\
\hline 2. & Kolam air deras (unit) & 32 & 136.62 & 42.70 \\
\hline 3. & Sawah (mina padi) (ha) & 5500 & 5593 & 10.17 \\
\hline 4. & Keramba (unit) & 74 & 210.94 & 28.50 \\
\hline
\end{tabular}

Keterangan: $\bar{x}=$ rataan; $\mathrm{s}=$ standar deviasi; $\mathrm{n}=105$ orang.

\section{Kapasitas Akses Input Produksi}

Kemampuan pembudidaya ikan dalam menyediakan dan memperoleh sarana produksi perikanan, baik berupa modal usaha, induk ikan, benih ikan, pakan, peralatan dan sarana produksi lainnya tergolong pada kategori sedang. Pembudidaya ikan sudah cukup mampu memperoleh ataupun menyediakan sarana produksi perikanan secara tepat waktu, tepat mutu dan tepat jumlah sesuai kebutuhan usaha. Baru sejumlah $35,24 \%$ pembudidaya yang menyatakan penyediaan sarana produksi difasilitasi oleh kelompok sedangkan yang lainnya disediakan sendiri (masing-masing) atau dibeli secara kolektif dengan sesama pembudidaya yang lain.

Kebutuhan modal untuk pembiayaan usaha sebagian besar berasal dari modal sendiri dan pinjaman pribadi pada pembudidaya yang lain. Sebagian kecil pembudidaya ikan

Tabel 3 Distribusi kapasitas pembudidaya ikan dalam pengelolaan usaha akuakultur

\begin{tabular}{|c|c|c|c|}
\hline Kapasitas Pembudidaya Ikan & Kategori & $\begin{array}{l}\text { Jumlah } \\
\text { (orang) }\end{array}$ & $\begin{array}{c}\text { Persentase } \\
(\%)\end{array}$ \\
\hline \multirow{4}{*}{$\begin{array}{l}\text { Kapasitas input produksi } \\
(\bar{x}=62.33 ; \mathrm{s}=15,92)\end{array}$} & Sangat Rendah (skor 0-25) & 1 & 0,95 \\
\hline & Rendah (skor 26-50) & 31 & 29,52 \\
\hline & Sedang (skor 51-75) & 46 & 43,81 \\
\hline & Tinggi (skor 76-100) & 27 & 25,71 \\
\hline \multirow{4}{*}{$\begin{array}{l}\text { Kapasitas pengelolaan produksi } \\
(\bar{x}=75.00 ; s=18,65)\end{array}$} & Sangat Rendah (skor 0-25) & 1 & 0,95 \\
\hline & Rendah (skor 26-50) & 6 & 5,71 \\
\hline & Sedang (skor 51-75) & 42 & 40,00 \\
\hline & Tinggi (skor 76-100) & 56 & $\mathbf{5 3 , 3 3}$ \\
\hline \multirow{4}{*}{$\begin{array}{l}\text { Kapasitas pemasaran produksi } \\
(\bar{x}=72.45 ; s=16,99)\end{array}$} & Sangat Rendah (skor 0-25) & 0 & 0 \\
\hline & Rendah (skor 26-50) & 19 & 18,10 \\
\hline & Sedang (skor 51-75) & 25 & 23,81 \\
\hline & Tinggi (skor 76-100) & 61 & $\mathbf{5 8 , 1 0}$ \\
\hline
\end{tabular}


$(7,61 \%)$ yang sumber permodalannya berasal dari pinjaman bank, koperasi, atau bermitra dengan pemilik modal (perseorangan). Meskipun demikian, pembudidaya ikan menyatakan relatif mampu memperoleh modal usaha tepat waktu sesuai dengan kegiatan produksi dan kebutuhan usaha. Ketersediaan air selama proses produksi relatif tersedia dengan baik, baik secara kualitas maupun kuantitasnya, begitu pula dengan pemenuhan sarana produksi lainnya. Tabel 4 menunjukkan kemampuan pembudidaya dalam mengakses input/sarana produksi.

Kemampuan pembudidaya ikan dalam memenuhi kebutuhan induk (usaha pembenihan) dan benih ikan (usaha pembesaran) relatif tinggi. Pembudidaya dapat dengan mudah memperoleh induk ataupun benih ikan dengan jumlah yang sesuai. Tingkat harga induk dan benih ikan relatif masih dapat dijangkau oleh pembudidaya, kecuali untuk induk strain tertentu yang harganya relatif tinggi (antara lain Nila Nirwana Rp 2,5 juta per paket induk). Sumber induk dan benih ikan diperoleh dari pembudidaya lokal setempat (ikan nilem, gurame) dan balai benih ikan untuk jenis ikan strain tertentu (Nila Nirwana). Sebagian kecil pembudidaya juga memperoleh bantuan paket induk dan benih dari dinas perikanan, balai benih ikan, dan program pemerintah pusat melalui mekanisme penyaluran bantuan sarana produksi kepada kelompok.

Akses pembudidaya ikan terhadap sarana produksi yang lain berupa pakan, peralatan, pupuk, dan obat-obatan juga menunjukkan kecenderungan yang sama. Sebagian besar pembudidaya ikan menyatakan memiliki akses yang cukup dalam memenuhi kebutuhan sarana usaha tersebut, baik dari segi jumlah, kualitas maupun harga. Kondisi skala usaha yang terbatas dan penerapan teknologi semi intensif menjadikan terbatasnya kebutuhan sarana produksi pembudidaya ikan. Pembudidaya ikan dalam pengelolaan usahanya masih mengandalkan pakan alami (plankton, tubifex, dedaunan) dan pakan tambahan berharga murah (dedak), sehingga biaya produksi untuk pakan ikan lebih rendah.

Hasil wawancara mendalam dengan beberapa pembudidaya ikan menunjukkan kekurangan lahan menjadi pembatas utama dalam mengembangkan usaha. Pembudidaya ikan yang berlokasi di luar sentra pengembangan budidaya ikan juga mengalami kendala dalam memperoleh induk ikan unggul

Tabel 4 Distribusi kemampuan pembudidaya dalam mengakses input produksi

\begin{tabular}{|c|c|c|c|}
\hline $\begin{array}{l}\text { Akses Pembudidaya Ikan } \\
\text { terhadap Input Produksi }\end{array}$ & Kategori & $\begin{array}{l}\text { Jumlah } \\
\text { (orang) }\end{array}$ & $\begin{array}{c}\text { Persentase } \\
(\%)\end{array}$ \\
\hline $\begin{array}{l}\text { Induk dan benih ikan } \\
(\bar{x}=3.07 ; s=0.63)\end{array}$ & $\begin{array}{l}\text { Sangat Rendah (skor } 1-1.75 \text { ) } \\
\text { Rendah (skor } 1.76-2.50 \text { ) } \\
\text { Sedang (skor } 2.51-3.25 \text { ) } \\
\text { Tinggi (skor } 3.26-4 \text { ) }\end{array}$ & $\begin{array}{c}1 \\
27 \\
31 \\
46\end{array}$ & $\begin{array}{c}0,95 \\
25,71 \\
29,53 \\
43,80 \\
\end{array}$ \\
\hline $\begin{array}{l}\text { Pakan ikan } \\
(\bar{x}=3.08 ; s=0.54)\end{array}$ & $\begin{array}{l}\text { Sangat Rendah (skor } 1 \text { - 1.75) } \\
\text { Rendah (skor } 1.76-2.50 \text { ) } \\
\text { Sedang (skor } 2.51 \text { - 3.25) } \\
\text { Tinggi (skor 3.26 - 4) }\end{array}$ & $\begin{array}{c}1 \\
17 \\
48 \\
39\end{array}$ & $\begin{array}{c}0,95 \\
16,19 \\
45,71 \\
37,14\end{array}$ \\
\hline $\begin{array}{l}\text { Peralatan } \\
(\bar{x}=3.09 ; s=0.57)\end{array}$ & $\begin{array}{l}\text { Sangat Rendah (skor } 1-1.75 \text { ) } \\
\text { Rendah (skor } 1.76-2.50 \text { ) } \\
\text { Sedang (skor } \mathbf{2 . 5 1}-\mathbf{3 . 2 5} \text { ) } \\
\text { Tinggi (skor } 3.26-4 \text { ) }\end{array}$ & $\begin{array}{c}1 \\
17 \\
54 \\
33\end{array}$ & $\begin{array}{c}0,95 \\
16,19 \\
\mathbf{5 1 , 4 3} \\
31,43\end{array}$ \\
\hline $\begin{array}{l}\text { Pupuk dan obat-obatan } \\
(\bar{x}=3.04 ; s=0.56)\end{array}$ & $\begin{array}{l}\text { Sangat Rendah (skor } 1-1.75 \text { ) } \\
\text { Rendah (skor } 1.76-2.50 \text { ) } \\
\text { Sedang (skor } 2.51-3.25 \text { ) } \\
\text { Tinggi (skor } 3.26-4 \text { ) }\end{array}$ & $\begin{array}{c}3 \\
17 \\
52 \\
33\end{array}$ & $\begin{array}{l}2,86 \\
16,19 \\
49,52 \\
31,43\end{array}$ \\
\hline
\end{tabular}

Keterangan: $\bar{x}=$ rataan skor; $\mathrm{s}=$ standar deviasi; $\mathrm{n}=105$ orang. 
dan harga pakan ikan yang relatif masih mahal.

\section{Kapasitas Pengelolaan Produksi Budidaya Ikan}

Kapasitas pengelolaan produksi dinilai dari kemampuannya dalam perencanaan dan pelaksanaan produksi proses produksi. Parameter pengukuran perencanaan produksi dinilai kemampuannya dalam; (a) menentukan jenis ikan yang diproduksi; (b) menentukan standar produksi; (c) mengatur siklus/pola produksi; dan (d) merencanakan kebutuhan sarana produksi (penghitungan kebutuhan benih, pupuk, pakan, dsb). Sedangkan parameter pengukuran proses produksi dinilai berdasarkan kemampuannya dalam menerapkan kaidah-kaidah budidaya dan aplikasi teknologi yang sesuai, mulai dari persiapan produksi sampai panen.

Hasil penelitian (Tabel 5) menunjukkan kemampuan pembudidaya ikan dalam mengelola usaha budidaya ikan (on farm) berada pada kategori tinggi. Hal ini mengindikasikan sebagian besar pembudidaya secara umum dengan kaidah dan standar minimal usaha budidaya ikan.

Pengelolaan usaha budidaya ikan sudah dilakukan berdasarkan perencanaan produksi yang telah disusun. Lebih dari setengah pembudidaya ikan $(54,29 \%)$ sudah melakukan pengaturan jadwal produksi, mulai dari penetapan waktu persiapan wadah budidaya sampai dengan waktu panen. Sebagian besar pembudidaya pada awal produksi juga sudah menghitung, menentukan dan mengendalikan kebutuhan modal dan sarana usaha, termasuk jenis dan target ukuran ikan yang ingin dipanen sesuai dengan permintaan pembeli. Pembudidaya ikan umumnya tidak memiliki tenaga kerja khusus yang digaji, penambahan tenaga kerja umumnya hanya dilakukan pada awal (persiapan kolam) atau akhir proses produksi (kegiatan panen).

Sebagian besar pembudidaya $(39,05 \%)$ dalam pelaksanaan proses produk-si sudah melakukan seleksi induk yang akan dipijahkan. Pembudidaya ikan sudah memperhatikan umur induk, berat induk, kondisi morfologi

Tabel 5 Tingkat penerapan pengelolaan produksi budidaya ikan (on farm) oleh pembudidaya ikan berdasarkan tahapan kegiatan usaha

\begin{tabular}{|c|c|c|c|c|c|c|c|c|c|}
\hline \multirow{2}{*}{ No } & \multirow{2}{*}{$\begin{array}{c}\text { Kegiatan Pengelolaan Produksi } \\
\text { Budidaya (On Farm) }\end{array}$} & \multicolumn{2}{|c|}{ Tidak } & \multicolumn{2}{|c|}{ Jarang } & \multicolumn{2}{|c|}{ Sering } & \multicolumn{2}{|c|}{ Selalu } \\
\hline & & $\mathbf{n}$ & $\%$ & $\mathbf{n}$ & $\%$ & $\mathbf{N}$ & $\%$ & $\mathbf{n}$ & $\%$ \\
\hline & Perencanaan Produksi & & & & & & & & \\
\hline 1. & $\begin{array}{l}\text { Menyusun jadwal produksi dan pengaturan } \\
\text { pola tanam }\end{array}$ & 4 & 3,81 & 11 & 10,48 & 33 & 31,43 & 57 & 54,29 \\
\hline 2. & Menghitung kebutuhan biaya dan sarana & 0 & 0 & 19 & 18,10 & 31 & 29,52 & 55 & $\mathbf{5 2 , 3 8}$ \\
\hline 3. & Menentukan jenis ikan dan standar produksi & 0 & 0 & 9 & 8,57 & 40 & 38,10 & 56 & 53,33 \\
\hline 4. & Mengatur tenaga kejja & 10 & 9,52 & 19 & 18,10 & 39 & 37,14 & 37 & 35,24 \\
\hline 5. & Membuat catatan perkembangan usaha & 6 & 5,71 & 29 & 27,62 & 47 & 44,76 & 23 & 21,90 \\
\hline 1. & $\begin{array}{l}\text { Pelaksanaan Produksi } \\
\text { Seleksi induk (pembenihan) }\end{array}$ & 9 & 8,57 & 22 & 20,94 & 33 & 31,43 & 41 & 39,05 \\
\hline 2. & Persiapan kolam/wadah budidaya & 0 & 0 & 16 & 15,23 & 39 & 37,14 & 50 & 47,62 \\
\hline 3. & Pengontrolan air & 0 & 0 & 7 & 6,67 & 52 & 49,52 & 46 & 43,81 \\
\hline 4. & Penghitungan padat tebar benih & 0 & 0 & 16 & 15,24 & 55 & 52,38 & 34 & 32,38 \\
\hline 5. & Seleksi benih yang ditebar (pembesaran) & 2 & 1,90 & 12 & 11,43 & 45 & 42,86 & 46 & 43,81 \\
\hline 6. & Pemberian pakan yang tepat/sesuai & 1 & 0,95 & 13 & 12,38 & 31 & 29,52 & 60 & 57,14 \\
\hline 7. & Pencegahan hama penyakit & 2 & 1,90 & 8 & 7,62 & 49 & 46,67 & 46 & 43,81 \\
\hline 8. & Sanpling pemeliharaan/ pertumbuhan & 5 & 4,76 & 16 & 15,24 & 63 & 60,00 & 21 & 20.00 \\
\hline 9. & Penentuan waktu panen & 0 & 0 & 6 & 5,71 & 43 & 40,95 & 56 & 53,33 \\
\hline 10. & Penentuan standar panen & 0 & 0 & 3 & 2,86 & 33 & 31,43 & 69 & 65,71 \\
\hline
\end{tabular}


memeriksa kematangan gonad sebelum dipijahkan. Tingkat perlakuan terhadap tahapan produksi lainnya juga relatif selalu dilakukan oleh pembudidaya ikan, antara lain pada persiapan kolam/wadah budidaya (pengeringan, perbaikan, dan pemupukan kolam), seleksi benih yang ditebar, pemberian pakan sesuai kebutuhan, teknis panen dan pasca panen. Perlakuan yang masih kurang dan perlu ditingkatkan adalah pada pencegahan hama penyakit dan sampling pertumbuhan ikan. Kendala usaha yang dialami pembudidaya adalah kegagalan produksi dan tingginya serangan hama penyakit pada musim kemarau. Penurunan produksi benih ikan biasanya terjadi pada bulan Juni sampai Agustus (musim dingin) karena pengaruh perubahan musim dan rentannya ikan terhadap serangan penyakit.

\section{Kapasitas Pemasaran Produksi}

Kapasitas pemasaran produksi didasarkan atas tiga aspek yang merupakan bagian dari bauran pemasaran (marketing mix) yaitu; (a) produk yang dipasarkan (product) meliputi kesesuaian spesifikasi produk (ukuran/size, mutu, dan jenis) dengan permintaan dan jumlah produk yang terserap pasar; (b) lokasi pemasaran (place) meliputi wilayah pemasaran dan saluran pemasaran (rantai tata niaga); dan (c) tingkat harga produk (price) yang diperoleh pembudidaya.

Sebagian besar pembudidaya ikan $(67,62 \%)$ menyatakan produksi ikan yang dihasilkan sudah sesuai dengan permintaan pembeli. Setiap jenis ikan baik benih pada berbagai ukuran maupun ikan konsumsi dapat diserap pasar, hanya $10-15 \%$ ikan yang tidak dapat terjual pada sebagian kecil pembudidaya ikan. Penjualan hasil produksi umumnya dilakukan secara kolektif di kelompok atau dijual langsung kepada pembeli yang datang ke lokasi usaha. Sebaran penjualan hasil produksi oleh pembudidaya ikan adalah: (a) dijual kepada pedagang pengumpul $(17,14 \%)$; (b) dijual secara kolektif dengan pembudidaya ikan lain secara terbatas $(2,86 \%)$; (c) dikumpulkan dan dijual secara kolektif di kelompok $(39,05 \%)$; dan (d) dijual lang-

Tabel 6. Jenis, ukuran dan harga jual ikan di Kabupaten Tasikmalaya, 2016

\begin{tabular}{|c|c|c|c|c|c|c|c|}
\hline No & $\begin{array}{c}\text { Jenis dan Uhuran } \\
\text { Ikan }\end{array}$ & Satuan & $\begin{array}{c}\text { Harga Jual } \\
\text { (Rp) }\end{array}$ & No & $\begin{array}{c}\text { Jenis dan Ukuran } \\
\text { Ikan }\end{array}$ & Satuan & $\begin{array}{c}\text { Harga Jual } \\
\text { (Rp) }\end{array}$ \\
\hline \multirow[t]{12}{*}{1.} & Gurame & & & & & & \\
\hline & - Telur & butir & $25-40$ & 3. & Mas & & \\
\hline & - Biji mentimun & elkor & $125-150$ & & - Fingerling $(1-3 \mathrm{~cm})$ & $\mathrm{kg}$ & 45.000 \\
\hline & - Biji labu & elkor & $200-250$ & & - Koral (3-5 cm) & $\mathrm{kg}$ & 35.000 \\
\hline & - Kula & elkor & $400-500$ & 4 & - Konsumsi & $\mathrm{kg}$ & $25.000-32.000$ \\
\hline & - Jempol & elkor & $600-700$ & & - Fingerling $(1-3 \mathrm{~cm})$ & $\mathrm{kg}$ & 25.000 \\
\hline & - Silet & elkor & $1.200-1.500$ & & - Koral (3-5 cm) & $\mathrm{kg}$ & 17.000 \\
\hline & - Korek api & elkor & $1.800-2.500$ & & - Konsumsi & $\mathrm{kg}$ & 22.000 \\
\hline & - Pahpir & elkor & $2.500-3.250$ & 5. & Tawes & & \\
\hline & - Bunghus rokok & elkor & $3.500-5.000$ & & - Fingerling $(1-3 \mathrm{~cm})$ & $\mathrm{kg}$ & 55.000 \\
\hline & - Kaset & elkor & $5.000-7.000$ & & - Koral (3-5 cm) & $\mathrm{kg}$ & 33.000 \\
\hline & & & & 6. & $\begin{array}{l}\text { - Konsumsi } \\
\text { Bawal air tawar }\end{array}$ & $\mathrm{kg}$ & 25.000 \\
\hline \multirow[t]{6}{*}{2.} & Nilem & & & & - Benih & ekor & 500 \\
\hline & - Larva & cangkir & 10.000 & & - Konsumsi & kg & 18.000 \\
\hline & - Aruy & $\mathrm{kg}$ & $27.000-32.000$ & 7. & Tambakan & & \\
\hline & - Huripan & $\mathrm{kg}$ & $26.000-30.000$ & & - Fingerling $(1-3 \mathrm{~cm})$ & $\mathrm{kg}$ & 55.000 \\
\hline & - Koral & $\mathrm{kg}$ & $18.000-23.000$ & & - Koral (3-5 cm) & $\mathrm{kg}$ & 27.000 \\
\hline & - Konsumsi & $\mathrm{kg}$ & $17.000-22.000$ & & - Konsumsi & $\mathrm{kg}$ & 30.000 \\
\hline
\end{tabular}

Sumber: Data primer, 2016 
sung kepada pembeli atau pasar (40,95\%). Hasil produksi sebagian besar dipasarkan di area Kabupaten dan Kota Tasikmalaya, Kabupaten Ciamis, Banjar, Garut dan Sukabumi.

Sebagian besar pembudidaya ikan $(47,62 \%)$ menyatakan kondisi harga jual ikan cukup baik dan wajar. Terdapat persaingan produk dari wilayah lain (terutama untuk benih ikan gurame) dengan harga jual yang lebih rendah, namun $71,43 \%$ pembudidaya ikan menyatakan produk dari wilayah lain tersebut tidak mengganggu serapan produksi setempat. Jenis, ukuran dan harga jual ikan di Kabupaten Tasik-malaya pada tahun 2016 ditunjukkan pada Tabel 6.

\section{Kinerja Usaha Anggota Kelompok Pembudidaya Ikan}

Kinerja usaha anggota kelompok pembudidaya ikan dinilai dari tingkat produktivitas dan pendapatan usaha budidaya (keuntungan) yang diperoleh selama satu tahun. Hasil penelitian menunjukkan rata-rata tingkat produktivitas usaha pembenihan ikan adalah 316 ekor $/ \mathrm{m}^{2} /$ tahun, sedangkan tingkat produktivitas usaha pembesaran ikan adalah $2,78 \mathrm{~kg} / \mathrm{m}^{2} /$ tahun. Nilai ini jauh dibawah rata-rata produktivitas kabupaten yaitu untuk pembenihan ikan 633 ekor/ $\mathrm{m}^{2} /$ tahun, sedang untuk produktivitas pembesaran ikan di atas ratarata kabupaten yang hanya $0,81 \mathrm{~kg} / \mathrm{m}^{2-}$ /tahun.

Rataan tingkat pendapatan yang diperoleh pembudidaya ikan dari usaha akuakultur adalah Rp 17.266.331/RTP/tahun. Nilai pendapat-an perikanan ini masih lebih rendah jika dibandingkan dengan angka kesejahteraan Bank Dunia, dimana pengeluaran per orang harus lebih besar dari 2 USD/hari. Mmpertimbangkan ukuran rata-rata keluarga di pedesaan adalah 5 orang dan yang bekerja hanya ayah dan atau ibu saja, maka pendapatan perikanan yang menyejahterakan pembudidaya ikan

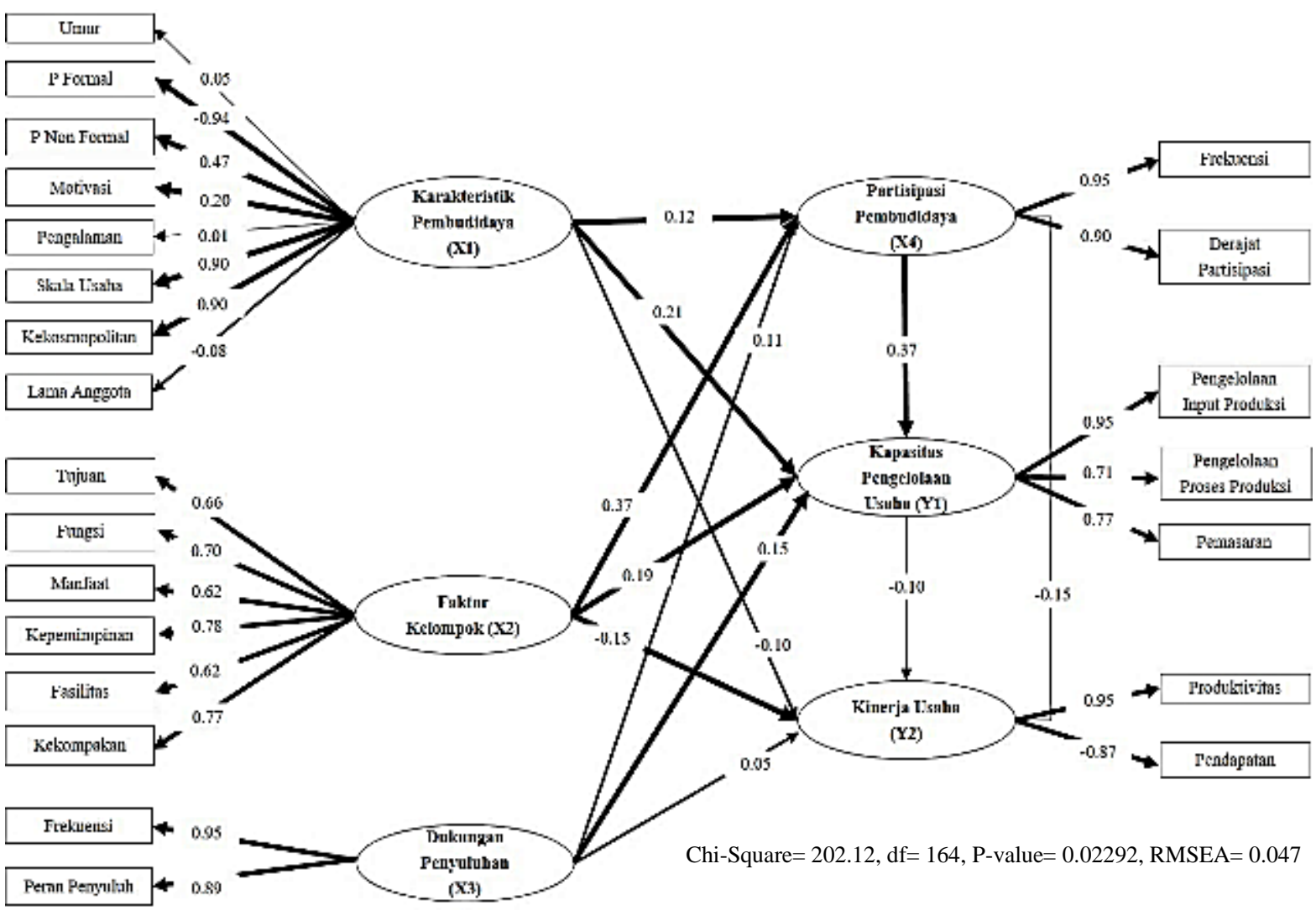

Gambar 3 Estimasi parameter hybrid model (standardized) faktor dominan yang memengaruhi kapasitas pengelolaan dan kinerja usaha pembudidaya ikan dalam kelompok 
adalah 300 USD/RTP/bulan, sekitar Rp 4 juta/RTP/bulan atau Rp 48 juta/RTP/tahun.

Nilai rataan $\mathrm{R} / \mathrm{C}$ ratio usaha budidaya ikan, baik pembesaran maupun pembenihan adalah 1,96 (standar deviasi 0,76 ) yang menunjukkan usaha budidaya ikan dinilai masih layak dan menguntungkan. Jika dibandingkan dengan modal usaha yang dikeluarkan oleh pembudidaya, hasil produksi usaha budidaya ikan seluruhnya memberikan keuntungan dengan nilai yang berbeda bagi pembudidaya. Adapun sebaran pembudidaya ikan berdasarkan nilai $\mathrm{R} / \mathrm{C}$ ratio usaha budidaya ikan adalah: (a) tingkat pendapatan rendah sejumlah $26,66 \%$; (b) tingkat pendapatan menengah sejumlah 47,62\%; dan (c) tinggi pendapatan tinggi sejumlah 25,71\%. Meskipun menguntungkan, rerata tingkat pendapatan dari usaha budidaya ikan masih rendah dibawah standar minimal kesejahteraan.

\section{Analisis Faktor yang Memengaruhi \\ Kapasitas dan Kinerja Usaha Anggota Kelompok Pembudidaya Ikan}

Analisis terhadap faktor-faktor yang memengaruhi kapasitas pengelolaan dan kinerja usaha anggota kelompok pembudidaya ikan dilakukan dengan analisis SEM (Structural Equation Models). Model hubungan antar faktor dominan yang memengaruhi kapasitas pengelolaan dan kinerja usaha pembudidaya ikan dalam kelompok disajikan pada Gambar 3.

Hasil pengujian terhadap kesesuaian model diketahui bahwa ukuran Goodness of Fit, yaitu RMSEA= 0,073 $(\leq 0,08)$; GFI $=0,93(\geq 0,90)$; $\mathrm{AGFI}=$ $0,90(\geq 0,90)$; dan CFI= 0,96 $(\geq 0,90)$, menunjukkan bahwa sebagian atau seluruh indikator menunjukkan bahwa model SEM sudah Fit atau sudah baik.

\begin{tabular}{|c|c|c|c|c|c|c|}
\hline \multirow{2}{*}{\multicolumn{2}{|c|}{ Hubungan antar variabel }} & \multirow{2}{*}{$\begin{array}{c}\text { Nilai } \\
\text { Koefisien } \\
\text { Pengaruh } \\
\text { Langsung } \\
\end{array}$} & \multicolumn{2}{|c|}{$\begin{array}{c}\text { Nilai Koefisien } \\
\text { Pengaruh Tidak } \\
\text { Langsung melalui } \\
\end{array}$} & \multirow[t]{2}{*}{ Total } & \multirow[t]{2}{*}{$\begin{array}{c}\text { Nilat t } \\
\text { pada } \\
\alpha=0.05\end{array}$} \\
\hline & & & Partisipasi & Kapasitas & & \\
\hline $\begin{array}{l}\text { Karalkteristik } \\
\text { pembudidaya }\end{array}$ & \multirow{3}{*}{$\begin{array}{l}\text { Partisipasi } \\
\text { dalam } \\
\text { Kelongok }\end{array}$} & 0,12 & - & - & 0,12 & $2,49 *$ \\
\hline Falktor kelompolk & & 0,36 & - & - & 0,36 & $6,50^{*}$ \\
\hline $\begin{array}{l}\text { Dulhungan } \\
\text { peryuluhan }\end{array}$ & & 0,11 & - & - & 0,11 & 1,13 \\
\hline $\begin{array}{l}\text { Karalkteristik } \\
\text { pembudidaya }\end{array}$ & \multirow{4}{*}{$\begin{array}{l}\text { Kapasitas } \\
\text { Pengelolaan } \\
\text { Usaha }\end{array}$} & 0,20 & 0,05 & - & 0,25 & $4,08 *$ \\
\hline Falktor kelompolk & & 0,17 & 0,14 & - & 0,31 & $2,80^{*}$ \\
\hline $\begin{array}{l}\text { Dulhugan } \\
\text { peryuluhan }\end{array}$ & & 0,14 & 0,04 & - & 0,18 & $2,04^{*}$ \\
\hline Partisipasi & & 0,39 & - & - & 0,39 & $4,72^{*}$ \\
\hline \multirow{2}{*}{$\begin{array}{l}\text { Karakteristik } \\
\text { pembudidaya } \\
\text { Falktor kelompols }\end{array}$} & \multirow{4}{*}{$\begin{array}{l}\text { Kinerja } \\
\text { Usaha } \\
\text { Pembudidaya }\end{array}$} & $-0,07$ & - & $-0,06$ & $-0,13$ & 0,96 \\
\hline & & $-0,25$ & - & $-0,11$ & $-0,36$ & $3,29 *$ \\
\hline \multirow{2}{*}{$\begin{array}{l}\text { Dulungan } \\
\text { peryuluhan } \\
\text { Partisipasi }\end{array}$} & & 0,14 & - & $-0,05$ & 0,09 & 1,74 \\
\hline & & $-0,13$ & - & $-0,08$ & $-0,21$ & 1,32 \\
\hline Kapasitas & $\rightarrow$ & $-0,20$ & - & - & $-0,20$ & 1,82 \\
\hline
\end{tabular}

Tabel 7 Dekomposisi pengaruh antar variabel penelitian 
Ukuran GFI dan AGFI yang masing-masing analog dengan statistik $\mathrm{R}^{2}$ dan adjusted $\mathrm{R}^{2}$ dalam analisis regresi, menunjukkan nilai masingmasing $\geq 0,90$ sehingga secara keseluruhan model struktural faktor dominan yang memengaruhi kapasitas pengelolaan usaha dan kinerja usaha pembudidaya ikan yang dianalisis sudah fit. Berdasarkan model tersebut dapat dijelaskan hubungan kausal (baik pengaruh langsung maupun tidak langsung) antar variabel penelitian yang secara ringkas dirangkum pada Tabel 7.

Hasil analisis menunjukkan terdapat pengaruh positif dan signifikan antara karakteristik pembudidaya ikan, faktor dukungan kelompok, dan keterlibatannya dalam kegiatan kelompok terhadap kapasitas pengelola-an usaha pembudidaya ikan. Hal ini berarti jika seluruh variabel meningkat maka akan berpengaruh langsung terhadap peningkatan kompetensi pembudidaya ikan dalam pengelolaan usaha, baik kemampuannya dalam mengakses input produksi, melaksanakan proses produksi (on farm), dan memasarkan hasil produksi. Spencer dan Spencer (1993) menyatakan kompetensi didasari oleh karakteristik individu dan karakteristik individu ini akan memengaruhi perilaku, tindakan dan kinerjanya. Penelitian Haqiqiansyah (1999) menunjukkan perilaku partisipasi yang cenderung tinggi dapat meningkatkan penerapan teknologi intensifikasi pada tambak udang. Semakin tinggi partisipasi dalam kelompok tani maka semakin banyak informasi yang dapat meningkatkan kemampuan petani dalam memanfaatkan teknologi. Anantanyu (2008) juga mengemukakan hasil yang sama bahwa petani dengan partisipasi yang tinggi cenderung memiliki tingkat kapasitas yang tinggi. Hal ini umumnya terjadi pada kelembagaan kelompok beranggotakan petani yang mempunyai kesadaran untuk bertindak kolektif. Dengan demikian hipotesis pertama yang menyatakan kapasitas pembudidaya dalam mengelola usaha dipengaruhi oleh keterlibatan pembudidaya dalam kelompok, karakteristik individu, faktor dukungan kelompok, dan tingkat dukungan layanan penyuluhan diterima.

Kondisi berbeda pada faktor yang mempengaruhi kinerja usaha pembudidaya sebagai anggota kelompok. Hasil analisis menunjukkan variabel yang berpengaruh signifikan adalah faktor dukungan kelompok pembudidaya ikan, sedangkan variabel yang lain tidak berpengaruh signifikan terhadap kinerja (hipotesis tidak diterima). Variabel dukungan kelompok memiliki pengaruh positif terhadap tingkat pendapatan, namun berpengaruh negatif terhadap produktivitas usaha. Hal ini berarti tingginya faktor dukungan kelompok walaupun dapat meningkatkan pendapatan namun belum berpengaruh secara signifikan terhadap peningkatan produktivitas usaha budidaya ikan bahkan cenderung menurunkan hasil produksi. Kondisi ini diakibatkan oleh beberapa hal antara lain; (1) adanya pola pembagian insentif kelompok (margin harga penjualan ikan, bantuan sarana produksi) yang berbeda antara ketua kelompok, pengurus dan anggota kelompok; dan (2) optimalisasi kegiatan kelompok belum sepenuhnya diarahkan pada orientasi usaha/bisnis.Penyediaan sarana produksi, upaya intensifikasi produksi, dan pemasaran sebagai hal yang utama dalam kegiatan usaha budi-daya, sebagian besar masih dilakukan oleh individu (masing-masing pembudidaya) sehingga peran nyata kelompok dalam memfasilitasi usaha anggotanya belum optimal. 


\section{SIMPULAN}

Kapasitas anggota kelompok pembudidaya dalam mengelola usaha akuakultur di Kabupaten Tasikmalaya tergolong pada kategori sedang sampai tinggi. Pembudidaya ikan cukup mampu menyediakan dan memperoleh sarana produksi perikanan, baik berupa modal usaha, induk ikan, benih ikan, pakan, dan peralatan secara tepat waktu, tepat mutu dan tepat jumlah sesuai kebutuhan usaha. Luasan lahan yang terbatas, ketersediaan induk ikan unggul dan relatif tingginya harga pakan menjadi pembatas utama dalam mengembangkan usaha. Pembudidaya juga sudah melakukan perencanaan dan pengendalian usaha sesuai dengan kaidah dan standar budidaya ikan, namun masih ada kegagalan produksi karena pengaruh perubahan musim dan serangan hama penyakit pada benih ikan. Hasil produksi yang dipasarkan pembudidaya juga sesuai dengan permintaan pembeli. Hampir seluruh jenis ikan baik benih pada berbagai ukuran maupun ikan konsumsi dapat diserap pasar dengan tingkat harga yang cukup baik dan wajar. Keberadaan kelompok bagi anggota belum mampu meningkatkan produktivitas usaha terutama pada usaha pembenihan ikan. Meskipun menguntungkan, nilai pendapatan dari usaha budidaya ikan masih rendah dan belum mampu menyejahterakan pembudidaya ikan dan keluarganya.

Variabel karakteristik pembudidaya ikan, dukungan kondisi kelompok, dukungan layanan penyuluhan, dan keterlibatan pembudidaya dalam kelompok, positif signifikan memengaruhi kapasitas pembudidaya ikan dalam pengelolaan usaha. Namun hanya variabel dukungan kelompok yang berpengaruh negatif signifikan terhadap tingkat produktivitas usaha dan berpengaruh positif signifikan terhadap tingkat pendapatan pembudidaya ikan, yang mengindikasikan harus adanya perbaikan manajemen kelembagaan kelompok pembudidaya ikan.

\section{DAFTAR PUSTAKA}

Anantanyu S. 2008. Tipe Petani dan Strategi Pengembangan Kelembagaan Kelompok Tani (Kasus di Provinsi Jawa Tengah). Jurnal M' Power. 8(8): 34-48.

Dahuri R. 2016. Akuakultur: Raksasa Ekonomi Indonesia yang Tertidur. Jakarta (ID): Republika.

Demaine H. 2009. Rural Aquaculture: Reflections Ten Years On. Di dalam M.G. Bondad Reantaso dan M. Prein, editor. Measuring the Contribution of Small-Scale Aquaculture: An Assessment. Rome, Italy (IT): FAO Fisheries and Aquaculture Technical Paper. 534:45-57.

Edwards P. 2000. Aquaculture, Poverty Impacts and Livelihoods. Natural Resources Perspective, Overseas Development Institute. 56(June 2000):1-4.

FAO. 2008. Present and Future Markets for Fish and Fish Products from Small- Scale Fisheries-Case Studies from Asia, Africa, and Latin America. Rome (IT): FAO.

Fatchiya A. 2010. Pola Pengembangan Kapasitas Pembudidaya Ikan Kolam Air Tawar di Provinsi Jawa Barat [disertasi]. Bogor (ID): Institut Pertanian Bogor.

$\begin{array}{rrr}\text { Haqiqiansyah G. } 1999 . & \text { Partisipasi } \\ \text { Petani } & \text { dalam } & \text { Kegiatan } \\ \text { Kelompok Tani Tambak Udang } \\ \text { di Kabupaten Kutai Kalimantan }\end{array}$ 
Timur [tesis]. Bogor (ID):

Resilience of Rural Livelihoods Institut Pertanian Bogor in Nepal. 2012(15):71-75. Nepal (NP) dan Malaysia (MY):

Shrestha MK, Pant J, Bhujel RC. 2012. Small Scale Aquaculture Development Model for Rural Nepal. Di dalam Shrestha MK dan Pant J, editor. Small Scale Aquaculture for Rural Livelihoods. Proceedings of the Symposium on Small Scale Aquaculture for Increasing Jointly Published Institute of Agriculture and Animal Science and The WorldFish Center.

Spencer LM, Spencer SM. 1993. Competence at Work: Models for Superior Performance. New York (US): John Wiley \& Sons, Inc. 